\title{
Identification and Validation of Reference Genes for qRT-PCR Studies of Gene Expression in Dioscorea opposita
}

\author{
Xiting Zhao, ${ }^{1,2,3}$ Xiaoli Zhang, ${ }^{1,2,3}$ Xiaobo Guo, ${ }^{1}$ Shujie Li, ${ }^{1}$ Linlin Han, ${ }^{1}$ Zhihui Song, \\ Yunying Wang, ${ }^{1} J^{\prime}$ hua $\mathrm{Li}^{1,2,3}$ and Mingjun $\mathrm{Li}^{1,2,3}$ \\ ${ }^{1}$ College of Life Sciences, Henan Normal University, Xinxiang 453007, China \\ ${ }^{2}$ Engineering Technology Research Center of Nursing and Utilization of Genuine Chinese Crude Drugs, University of Henan Province, \\ Xinxiang 453007, China \\ ${ }^{3}$ Henan Province Engineering Laboratory of Green Medicinal Plant Biotechnology, Xinxiang 453007, China
}

Correspondence should be addressed to Junhua Li; lijh0909@gmail.com and Mingjun Li; limingjun2002@263.net

Received 8 January 2016; Accepted 4 May 2016

Academic Editor: Young-Mi Lee

Copyright (C) 2016 Xiting Zhao et al. This is an open access article distributed under the Creative Commons Attribution License, which permits unrestricted use, distribution, and reproduction in any medium, provided the original work is properly cited.

\begin{abstract}
Quantitative real-time polymerase chain reaction (qRT-PCR) is one of the most common methods for gene expression studies. Data normalization based on reference genes is essential for obtaining reliable results for qRT-PCR assays. This study evaluated potential reference genes of Chinese yam (Dioscorea opposita Thunb.), which is an important tuber crop and medicinal plant in East Asia. The expression of ten candidate reference genes across 20 samples from different organs and development stages was assessed. We identified the most stable genes for qRT-PCR studies using combined samples from different organs. Our results also suggest that different suitable reference genes or combinations of reference genes for normalization should be applied according to different organs and developmental stages. To validate the suitability of the reference genes, we evaluated the relative expression of PE2.1 and PE53, which are two genes that may be associated with microtuber formation. Our results provide the foundation for reference gene(s) selection in D. opposita and will contribute toward more accurate gene analysis studies of the genus Dioscorea.
\end{abstract}

\section{Introduction}

Gene expression analysis has contributed to a better understanding of the function of candidate genes, which are involved in plant growth and development, as well as signal transduction and metabolism. Northern blotting, semiquantitative reverse transcription-PCR, and reverse transcription quantitative real-time PCR (qRT-PCR) [1] have each been used extensively in modern biological research. Among these, qRT-PCR has become a frequent first choice for gene expression studies, because of its high sensitivity, accuracy, and broad dynamic range [2-4]. Further, qRT-PCR has become the preferred method for many purposes such as clinical diagnosis, gene expression analysis in a specific tissue, or studies involving complex experiments and large numbers of genes [5-8]. Although it is widely used for gene expression analysis due to these advantages, qRT-PCR suffers from certain pitfalls such as differences in initial sample amount, RNA integrity issues, differences in the efficiency of cDNA synthesis, and differences in the overall transcriptional activity of the tissues or cells analyzed [3]; all of these factors can make the quantification of gene transcripts unreliable. To avoid bias, the selection of an appropriate normalization method becomes imperative for obtaining reliable quantitative gene expression results. The use of reference genes is commonly accepted as the most appropriate normalization strategy [9]. Consequently, the reliability of the quantitative results is highly dependent on the choice of appropriate reference genes for use in normalization.

Ideal reference genes should exhibit a constant level of expression in all tissues and development stages, independent of diverse experimental conditions. Moreover, reliable reference genes should have a transcript level similar to the target gene [10-13]. Housekeeping genes are commonly used as reference genes as they are typically supposed to have stable expression patterns. However, to date, more and more reports 
have demonstrated that there are no universally applicable reference genes with invariant expression levels, and inappropriate internal controls can lead to errors in the interpretation of biological data $[14,15]$. Thus, there is an urgent need to systematically evaluate the stability of potential reference genes for particular experimental systems prior to adopting them for use in qRT-PCR normalization strategies. There have been a number of studies on the validation of reference genes in different plants including model plants (Arabidopsis $[16,17]$, rice $[18,19]$, tomato $[20,21]$, tobacco [22], etc.), crop plants (soybean [23, 24], pea [25], sugarcane [26], coffee $[27,28]$, peanut [29], cotton [2,30], Brassica napus [15], wheat [31], etc.), vegetables (potato [8], chicory [32], cucumber [13], pepper [33], radish [34], etc.), fruits (berry [35], peach [36], banana [14], apple [37], etc.), flowers (petunia [38], rose $[39,40]$, etc.), tree plants, longan tree [41], and poplar [42]. Several algorithms such as geNorm [43], NormFinder [44], Best Keeper [45], and qBasePlus [46] have been developed to evaluate the most stable reference genes from among an input panel of candidate genes for a given set of experimental conditions.

Chinese yam (Dioscorea opposita Thunb.) is an important food and medicinal plant that is widely cultivated in East Asia. Modern scientific research has revealed that D. opposita has great health benefits [47-51]. Chinese yam is widely used as an ingredient in functional foods and drugs that enjoy great popularity in East Asia. Given its important medical and edible value, there is growing interest in this plant from the food and other industries. Thus, the production of D. opposita is gaining more attention. However, it is known that longterm vegetative propagation of $D$. opposita leads to serious virus infections and consequent losses in yield and quality. There is a desperate demand for improved resources and methods for high quality D. opposita production.

Propagation via virus-free plantlets can effectively solve the problems mentioned above, but the low survival rate and inconvenience of transporting these plantlets hinder the promotion and application of such methods. Propagation via microtubers and protocorm-like bodies (PLBs) that are induced from virus-free plantlets can overcome such shortcomings and is gaining attention rapidly. Microtubers are small tubers originating from tissues in vitro; they are more tolerant to stress conditions than plantlets and do not have the requirement of frequent subculturing as is needed for plantlet maintenance. Therefore, microtubers are attractive alternative to in vitro-grown plantlets for use as a means of micropropagation and exchange of healthy $D$. opposita materials. PLBs are undifferentiated tissue masses that outwardly resemble somatic embryos in form and development [52]; they have great potential for use as target explants for high frequency regeneration/propagation. The rooting of PLBs is endogenous and can resolve the problem of low survival rates that is known to be a problem with plantlets cultured in vitro [53]. The molecular mechanisms underlying the formation of microtubers and PLBs remain as yet unclear. Investigation of the key genes in microtuber and PLB formation will enable researchers to gain insight into the molecular basis of these processes. Some candidate genes related to microtuber formation in D. opposita were recently identified by transcriptome sequencing, and we have cloned genes involved in PLB formation in D. opposita. However, there has to date been little focus on which reference genes are well-suited for studies of microtuber and PLB formation in D. opposita; no well-defined and validated set(s) of reference genes have been described for D. opposita.

In this study, we evaluated ten different reference genes (ACT, APT, EF1- $\alpha$, GAPDH, TUB, UBQ, TIP41, MDH, PP2A, and $G U S B$ ) for their potential for use as internal normalization controls in $D$. opposita. The expression patterns of these reference genes were tested in a range of organ types and developmental stages to identify the most suitable genes for use as internal controls in qRT-PCR expression studies in $D$. opposita.

\section{Materials and Methods}

2.1. Plant Materials and Treatments. Experiments were performed using D. opposita cv. Tiegun. Germ-free materials were maintained as described previously [54]. PLBs were produced from nodal segments in Murashige and Skoog (MS) basal medium [55] supplemented with $3 \mathrm{mg} \mathrm{L}^{-1}$ thidiazuron, $3 \mathrm{mg} \mathrm{L}^{-1}$ kinetin, and $30 \mathrm{gL}^{-1}$ sucrose (our unpublished results); microtubers were produced as described previously [56].

Materials from three separate organs, including root, stem, and leaf, were collected at the same time ( $42 \mathrm{~d}$ after transfer to media); three different "sections" for each of the three organs were also collected: an upper part, a middle part, and a lower part. For PLBs, samples were collected at four different stages (our unpublished data). The first stage is the explant stage, during which a nodal segment is inoculated and the culture is initiated, named PLBs- 0 ; the second stage is the explant swelling stage; the white small protrusions appear at leaf axils during this stage, named PLBs-I; the third stage is the primary PLB stage; white small protrusions become large and turn into light green PLBs cluster during this stage, named PLBs-II; the 4th stage is the mature PLB stage; the light green PLBs cluster grows up and becomes ivory coloured, named PLBs-III. For PLBs, samples were collected at four different stages. For microtubers, samples were collected at seven different stages as previously described by Li et al. [56]: initial explant stage (DMT-0), budding stage (DMT-1), bud stretching stage (DMT-2), bud visible swelling stage (DMT3), microtuber initiation stage (DMT-4), microtuber enlargement stage (DMT-5), and microtuber mature stage (DMT-6). All samples were frozen in liquid nitrogen immediately after harvesting and stored at $-80^{\circ} \mathrm{C}$ until future use.

2.2. RNA Extraction and cDNA Synthesis. Total RNA was extracted from different samples with a TaKaRa Mini-BEST Plant RNA Extraction Kit (TaKaRa, Japan), including DNase I treatment, according to the manufacturer's instructions. The integrity of the total RNA was checked on 1\% agarose gels and RNA quantity and purity were evaluated by measuring the optical density at $260 \mathrm{~nm}$ and the A260/280 absorption ratio using a NanoDrop 2000 spectrophotometer (Thermo Fisher Scientific, US). cDNA synthesis was performed using $\mathrm{HiScript}^{\mathrm{TM}} \mathrm{Q}$ Select RT SuperMix for qPCR (Vazyme, China) 
following the manufacturer's instructions. For all samples, about $400 \mathrm{ng}$ of total RNA was used to generate cDNA samples using Oligo $(\mathrm{dT})_{18}$ primer in a final reaction volume of $10 \mu \mathrm{L}$. The cDNA products were diluted 10 -fold with nuclease-free water prior to use in the qRT-PCR assays.

2.3. Selection of Candidate Reference Genes. Based on previous reports of the effective application of reference genes for use in studies of various plant species $[8,16-18,23,35$, $36,41,42]$, we selected ten candidate reference genes for an investigation to identify the most stably expressed genes in various organs and developmental stages (Table 1). The ACT and GAPDH gene sequences were obtained by degenerate PCR and have been submitted to the National Center for Biotechnology Information (NCBI, USA), with accession numbers of KR361321 and KR361320, respectively (Supplemental Document 1, in Supplementary Material available online at http://dx.doi.org/10.1155/2016/3089584). The sequences of the eight other candidate reference genes, including TUB, TIP41, UBQ, PP2A, MDH, GUSB, APT, and $E F 1-\alpha$, were selected from our transcriptome database that was generated via high-throughput Illumina sequencing (Novogene, China, Supplemental Document 1). These ten genes belong to different functional classes and were thus chosen to reduce the chance of the occurrence of coregulated expression among the candidates.

2.4. Design and Validation of $q R T-P C R$ Primers. Specific primers were designed for qRT-PCR analysis using Primer 5 software (the sequences are listed in Table 1) with melting temperatures $\left(T_{\mathrm{m}}\right)$ of $55-61^{\circ} \mathrm{C}$, primer lengths of $17-25 \mathrm{bp}$, $40-60 \%$ GC content, and amplicon lengths of $80-200 \mathrm{bp}$. An exception to this was the amplicon length for the $M D H$ primers, which was $224 \mathrm{bp}$.

qRT-PCR was carried out in 96-well plates with an ABI 7500 Real-Time PCR System and 7500 System Software (Applied Biosystems, Alameda, CA, USA) using SYBR Green-based PCR assays. Each reaction mix contained $1 \mu \mathrm{L}$ of 10 -fold diluted cDNA, $10 \mu \mathrm{L}$ of EvaGreen 2x qPCR MasterMix (Applied Biological Materials Inc., Canada), $0.6 \mu \mathrm{L}$ of each primer, and nuclease-free water to a final volume of $20 \mu \mathrm{L}$. The thermal cycling program was as follows: $95^{\circ} \mathrm{C}$ for $10 \mathrm{~min}$, followed by 40 cycles of $95^{\circ} \mathrm{C}$ for $15 \mathrm{~s}$ and $60^{\circ} \mathrm{C}$ for $60 \mathrm{~s}$ in 96-well optical reaction plates (Bio-Rad, USA). The melting curves were analyzed at $60-95^{\circ} \mathrm{C}$ after 40 cycles. The amplification products were checked on $3 \%$ agarose gels. Each qRTPCR analysis was performed with three technical replicates.

The qRT-PCR efficiency was determined for the ten candidate reference genes and the two target genes based on the slope of a linear regression model [57]. For this, cDNA from different samples was bulked and then used as the PCR template. The corresponding qRT-PCR efficiencies $(E)$ were calculated according to the equation

$$
E=\left[10^{(1 /- \text { slope })}-1\right] \times 100 \%
$$

(see [58]).

For each gene, PCR efficiency was determined by measuring the mean threshold cycle $(\mathrm{Ct})$ to a specific threshold
$[59,60]$ for serial dilution of bulked cDNA. Five-point standard curves of a tenfold dilution series $(1: 1,1: 10,1: 100$, $1: 1000$, and $1: 10000)$ from pooled cDNA were used to calculate PCR efficiency. A standard curve was repeated in three dependent plates. The primer sequences and amplicon characteristics including $T_{\mathrm{m}}$, length, amplification efficiency with standard deviation (SD), and correlation coefficients of the ten candidate reference genes are listed in Table 1.

2.5. Statistical Analysis. The stability of the expression of each candidate gene was analyzed using the geNorm version 3.5 [43] and the NormFinder version 0.953 [44] using settings suggested in the geNorm and NormFinder user manuals. The $\mathrm{Ct}$ values were converted into relative expression values for the genes, and these values were used as the input for the geNorm and NormFinder programs. All other statistical analyses were performed with Microsoft Excel 2010.

2.6. Normalization of PE2.1 and PE53. To test whether the choice of different reference genes influenced the final normalized results, the expression patterns of PE2.1 (comp86916_c0) and PE53 (comp76893_c0) were analyzed in parallel. PE2.1 and PE53 are members of the pectinesterase (PE) superfamily. According to our transcriptome analyses of microtuber induction and formation of D. opposita (unpublished findings), these are likely to be genes associated with the regulation of the starch and sucrose metabolism and signaling pathways. Therefore, they may play important roles in microtuber formation. The primer pairs used for the qRTPCR analysis of these genes are listed in Table 1. The relative expression levels of PE2.1 and PE53 were estimated at three different development stages (DMT-0, DMT-3, and DMT-4) of microtuber formation, using five different normalization approaches: (1) with the most stable reference gene (APT); (2) with the two most stable reference genes selected by geNorm (TUB and $U B Q$ ); (3) with the two most stable reference genes identified by NormFinder (ACT and $A P T)$; (4) with the four reference genes suggested by both analyses (TUB, UBQ, ACT, and $A P T)$; (5) with picking up the least stable gene to act as a reference (GUSB). The relative expression of the target gene was calculated using the $2^{-\Delta \Delta C t}$ method [61]. The mRNA levels of the target genes at DMT-0 were employed as a calibrator and were set to 1 .

\section{Results}

3.1. RNA Quality Check. The quality of RNA samples is critical for successful gene expression analysis. We extracted total RNA from 20 different plant materials. Only RNA samples with both $28 \mathrm{~S}$ and $18 \mathrm{~S}$ ribosomal RNA bands with a density ratio of about 2.0 and without smears on $1 \%$ agarose gels were used for subsequent analysis. The value of the A260/280 ratio for all of the RNA samples was between 2.0 and 2.2 and the A260/230 ratio values for all samples were higher than 2.0, indicating that the RNA samples were of sufficient purity for use in $\mathrm{qRT}$-PCR assays, without contamination. 


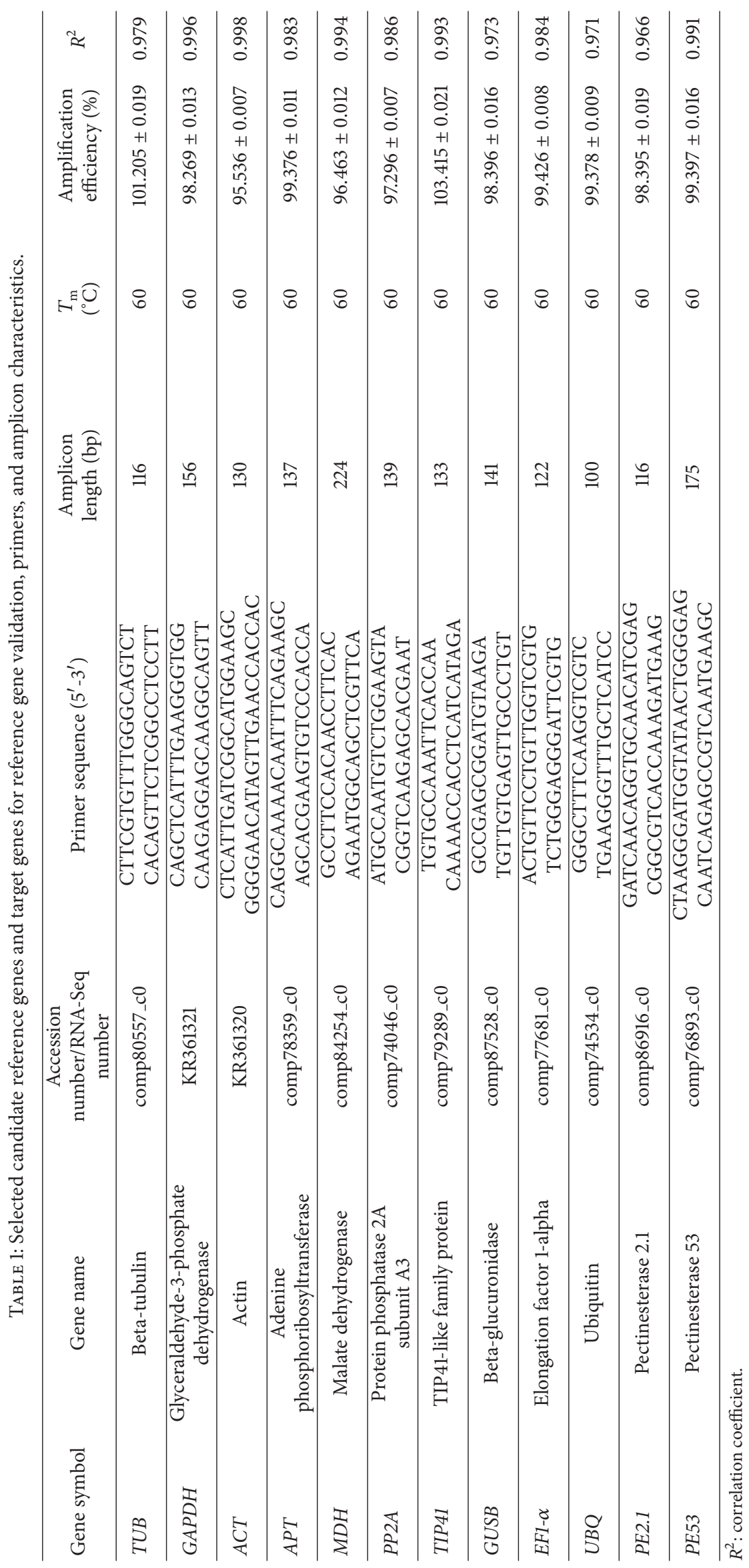



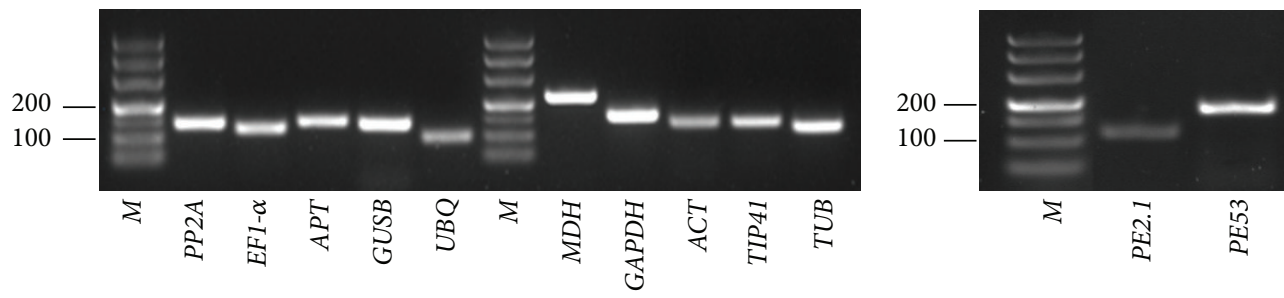

(a)

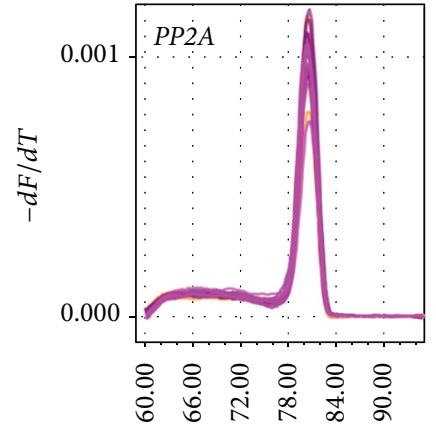

Temperature $\left({ }^{\circ} \mathrm{C}\right)$

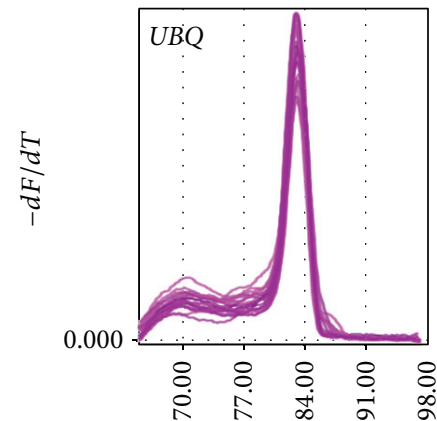

Temperature $\left({ }^{\circ} \mathrm{C}\right)$

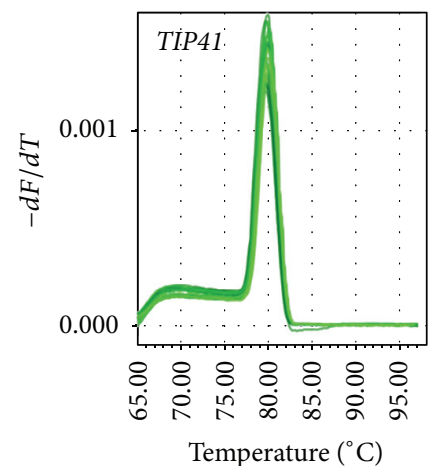

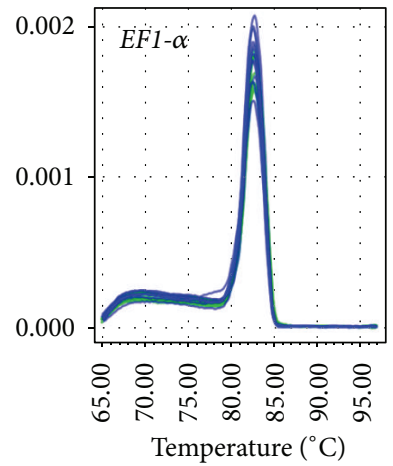

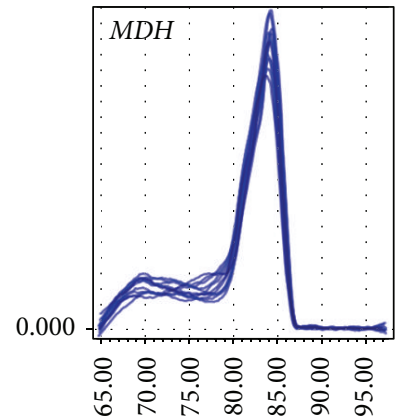

Temperature $\left({ }^{\circ} \mathrm{C}\right)$

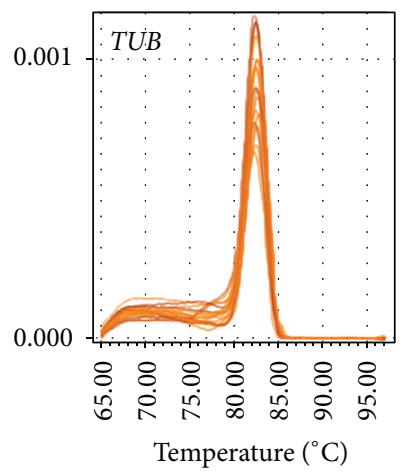

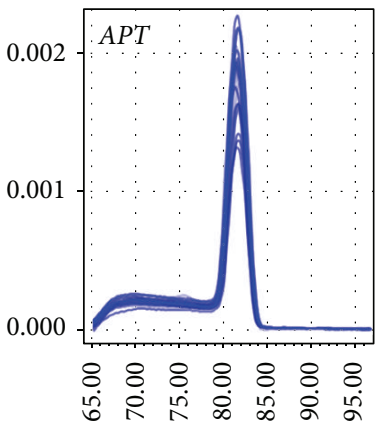

Temperature $\left({ }^{\circ} \mathrm{C}\right)$

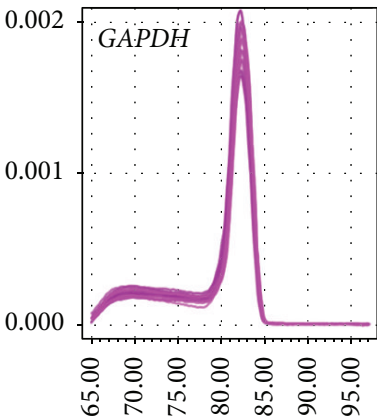

Temperature $\left({ }^{\circ} \mathrm{C}\right)$

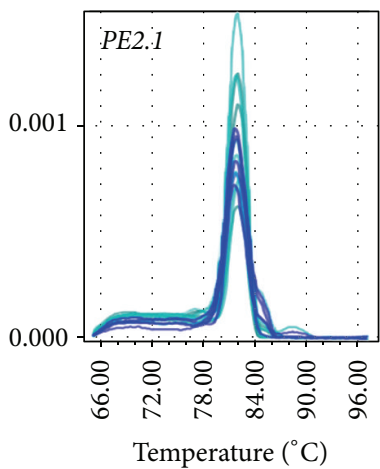

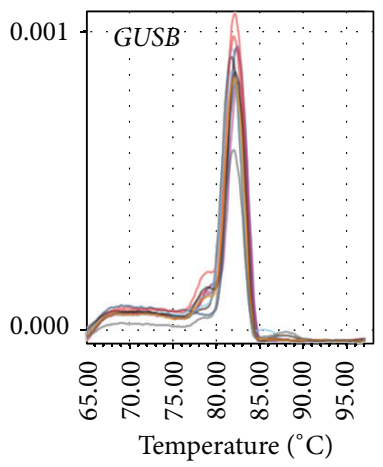

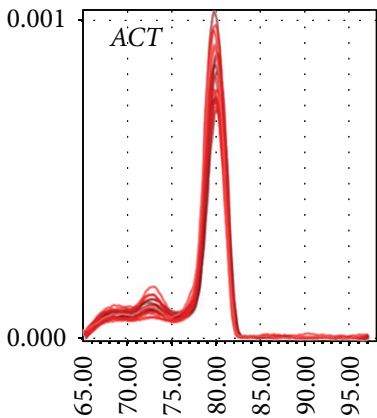

Temperature $\left({ }^{\circ} \mathrm{C}\right)$

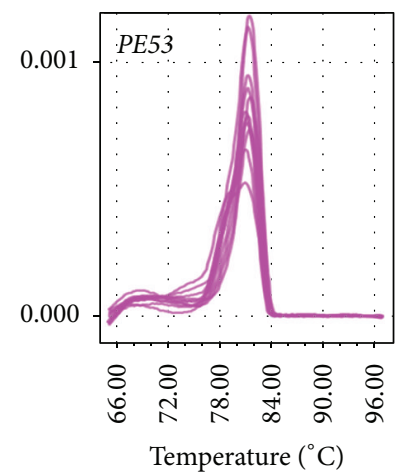

(b)

FIGURE 1: Specificity of qRT-PCR amplicons. (a) Agarose gel electrophoresis showing amplification of a single product of the expected size for each candidate gene and two target genes for reference gene validation. $M$ represents DL2,000 DNA marker. (b) Dissociation curves with single peaks generated for all amplicons.

3.2. Verification of Primer Specificity and PCR Efficiency Analysis. To check the specificity of the primers for these candidate reference genes and two target genes, agarose gel electrophoresis and melting curve analyses were performed following completion of the qRT-PCR assays. The results of the agarose gel electrophoresis indicated that all of the primer pairs amplified a single band of the expected respective size and formed no primer dimers or other nonspecific amplification products (Figure 1(a)). The specificity of the amplicons was further confirmed by the observation of a 


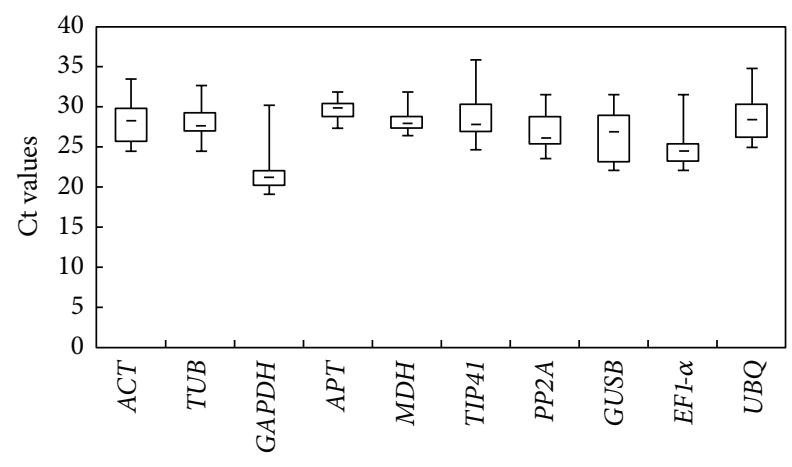

FIGURE 2: RNA transcription levels of reference genes tested, presented as $\mathrm{Ct}$ mean value in the different samples. Boxes indicate the 25 th/75th percentiles, lines across the boxes depict the medians, squares represent the means, and whiskers indicate the ranges for all samples.

single peak in the melting curve analyses after 40 cycles (Figure 1(b)). The PCR amplification efficiency for the ten reference and the two target genes varied from $95.536 \%$ for ACT to $103.415 \%$ for TIP41, and correlation coefficient $\left(R^{2}\right)$ values ranged from 0.966 to 0.998 over $10^{4}$ times of cDNA dilution for PE2.1 and ACT, respectively (Table 1).

3.3. Expression Profile of the Candidate Reference Genes. Ct values were used to analyze the steady-state mRNA levels of each reference gene [60]. To obtain reliable results, all qRTPCR assays were conducted with three technical replicates, and the mean values were used for expression profile analysis. Analysis of the Ct values across all samples indicated differences in the expression among the candidate reference genes (Figure 2), suggesting varying levels of transcript abundance for the ten genes analyzed. In all tested samples, the lowest mean Ct value (22.30) was exhibited by GAPDH, indicating the highest abundance among the reference genes, whereas $A P T$ showed lower levels of expression (mean $\mathrm{Ct}=29.65)$. $G A P D H$ and EF1- $\alpha$ showed higher expression levels than other genes in all tested samples, with the average Ct values ranging from 22.30 to 24.83 , while the other genes had lower expression levels, with average Ct values ranging from 26.36 to 29.65. The smallest variation in gene expression was observed for $A P T$ (4.47), while GAPDH (11.07) and TIP41 (10.88) were the genes with the most variable levels of expression. These results indicated that none of the selected genes had a constant level of expression in the different $D$. opposita samples tested. Therefore, it is extremely important to evaluate the suitability of particular reference genes for use in gene expression normalization under particular experimental conditions.

\subsection{Evaluation of the Expression Stability of Candidate Refer-} ence Genes. Since the 10 candidate reference genes showed wide variations in expression levels in the different samples, it was necessary to use statistical methods to rank the stability of expression of the 10 genes and determine the number of reference genes necessary for accurate gene expression profiling under a given experimental condition. Two different analysis programs, geNorm and NormFinder, were used in the following analysis. The raw $\mathrm{Ct}$ values were manually transformed into the geNorm and NormFinder data input formats and then analyzed by geNorm and NormFinder.

In the geNorm program, the average expression stability $(M)$ value for each gene was calculated based on the average pairwise variation between all genes tested. Stepwise exclusion of the least stable gene allows the genes to be ranked according to their $M$ value (the lower the $M$ value, the higher the gene's expression stability). The results obtained with the geNorm program are presented in Figure 3. Among the ten candidate reference genes, none of the reference genes had identical expression under different experiment conditions. The ACT and TUB genes ranked the highest for the different development stages of PLB formation, with an $M$ value of 0.452 . The TUB and $U B Q$ genes proved to be the best candidates for normalization in samples at different development stages during microtuber formation, with an $M$ value of 0.399 . For root samples, the most stable genes were $A C T$ and $T U B$, with an $M$ value of 0.131 . For stems, $P P 2 A$ and $A P T$ were the most stably expressed, with an $M$ value of 0.01. For leaves, EF1- $\alpha$ and GUSB exhibited the most stable expression, with an $M$ value of 0.059 . When different organ sample sets (root, stem, or leaf) were analyzed together, TIP41 and $P P 2 A$ were found to be the most stably expressed genes, with an $M$ value of 0.155 .

The geNorm program was also used here to calculate the optimal number of reference genes required for accurate normalization in the different sample sets. The software determines the pairwise variation $V n / n+1$, which measures the effect of adding further reference genes on the normalization factor (which is calculated as the geometric mean of the expression values of the selected reference genes). It is advisable to add additional reference genes to the normalization factor until the added gene has no significant effect. A cut-off value of 0.15 has been widely accepted as the criterion for selecting a suitable number of reference genes, below which the inclusion of additional reference genes is not needed [43]. However, 0.15 is not an absolute cut-off value, but rather an ideal value. In our study, the $V 2 / 3$ values of root, stem, leaf, and different organs were less than 0.15 , suggesting that the optimal number of reference genes for normalization in these groups was at least two. For microtubers, the pairwise variation value of $V 3 / 4$ was 0.169 and that of $V 4 / 5$ was 0.120 , suggesting that four reference genes were required (Figure 4).

NormFinder takes into account the intra- and intergroup variations for normalization factor (NF) calculations. The results for our study obtained with the NormFinder program are presented in Table 2. For the different development stages during PLB formation, the best combination recommended by NormFinder was $A C T$ and $T U B$, and the most stable gene was ACT. Combination of ACT and APT was found to be the best during the different development stages of microtuber formation, in which the APT was the optimal reference gene. For the combined analysis of root, stem, and leaf, the best gene combination was TIP41 and EF1- $\alpha$, and the most stable gene was TIP41. The combination of $M D H$ and UBQ was considered to be the best for leaves; if only one reference gene was to be used, UBQ would be the best choice for studies of 

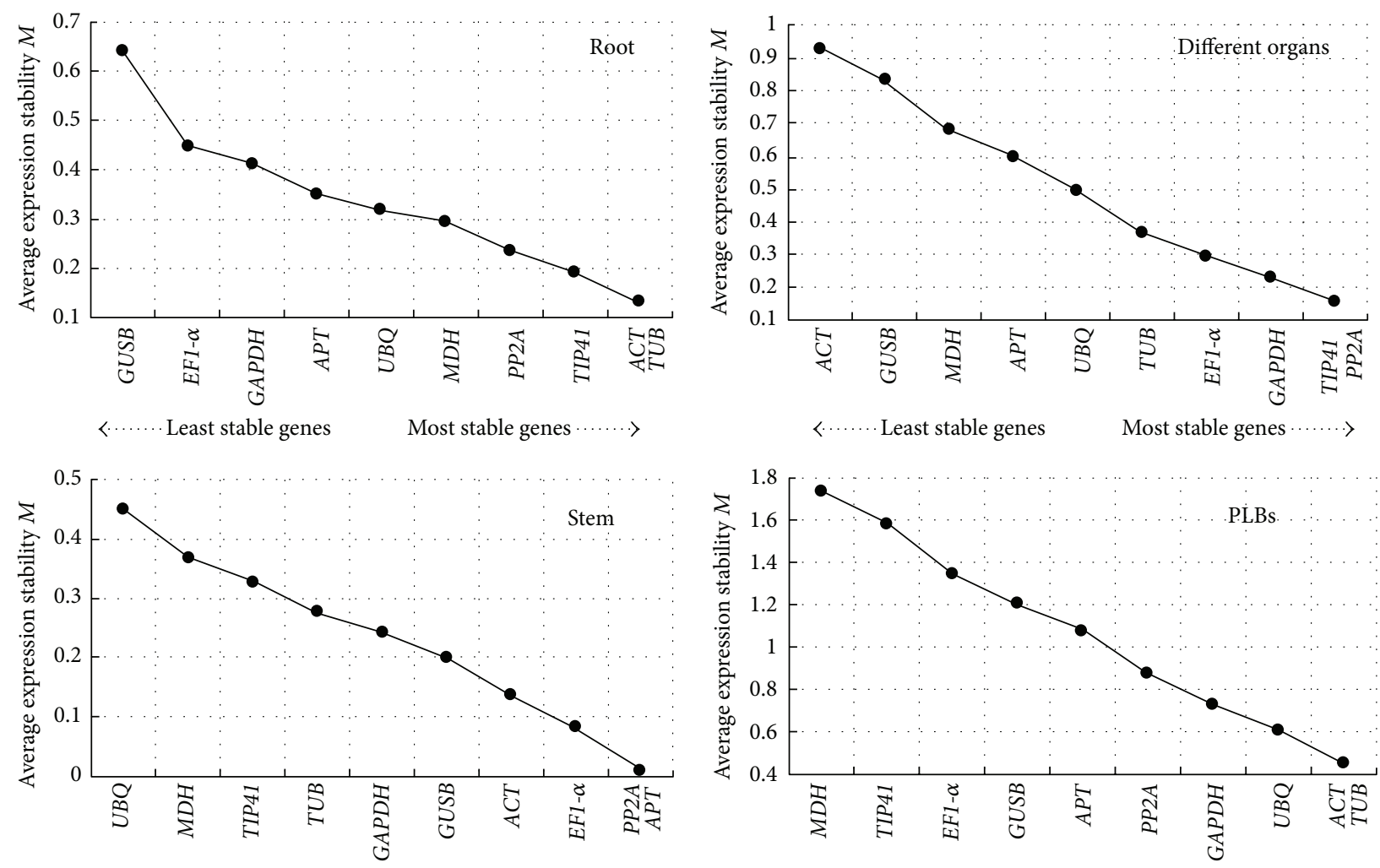

$\langle\ldots . .$. Least stable genes $\quad$ Most stable genes $\ldots . . . .$.

$\langle\ldots . .$. Least stable genes $\quad$ Most stable genes $\ldots . . .$.
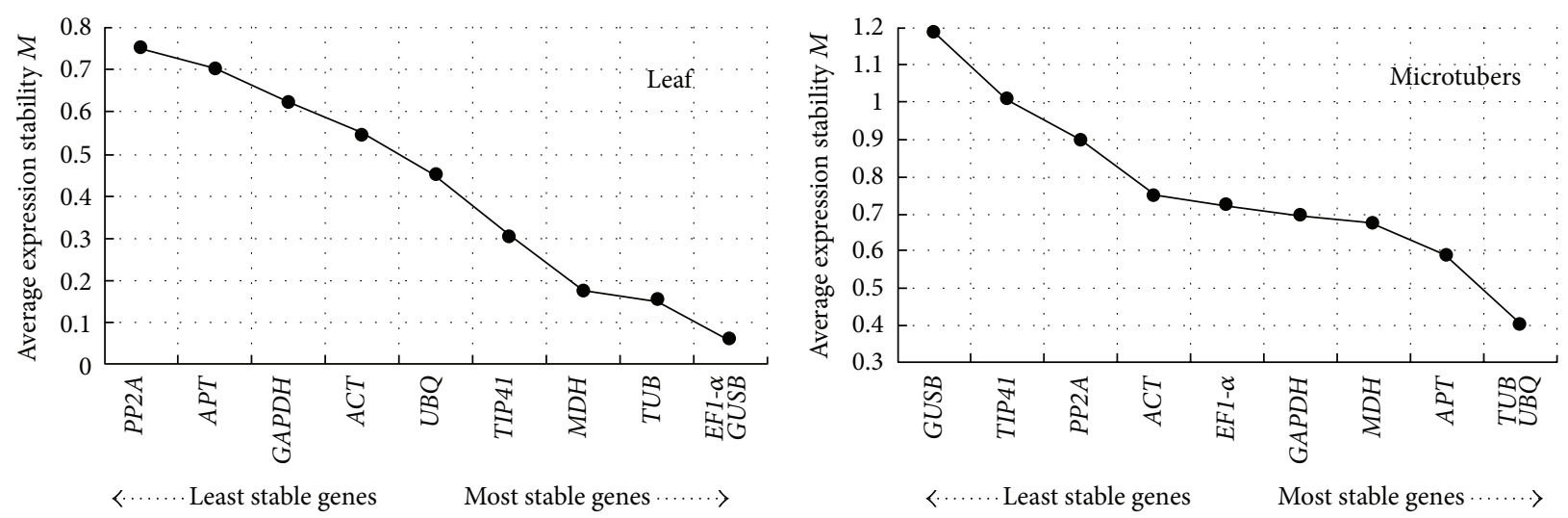

FIGURE 3: Gene expression stability and rankings of ten candidate reference genes, as calculated by geNorm software. The average expression stability $(M)$ was calculated following stepwise exclusion of the least stable gene across all the samples within an experimental set. The lowest $M$ value indicates the most stable gene, while the highest value represents the most highly variable gene.

leaves. The combination of $A P T$ and GUSB was found to be the most suitable for stems, and GUSB was the single most stable gene. For roots, the combination of PP2A and TIP41 was the best combination, and TIP41 was the most stable. In these cases, the most stable gene was consistent with the best combinations. No matter which of the programs was used, the most variable gene in roots was GUSB, the most variable gene in stems was $U B Q$, and the most variable gene in leaves was $P P 2 A . M D H$ was the least stable gene during PLB formation. GUSB was the most variable in both the different organ samples and microtuber formation.
3.5. Reference Gene Validation in Gene Expression Study. The expression of $D$. opposita genes encoding two PE enzymes was analyzed by qRT-PCR in order to validate the performance of the selected candidate genes as internal controls for normalization. GUSB was the most unstable gene for normalization according to the geNorm and NormFinder analysis. When GUSB alone was used as the reference, the expression level of PE2.1 increased 368-fold at the bud visible swelling stage (DMT-3) as compared to its expression at the explants stage (DMT-0). PE2.1 expression was increased 147fold at the microtuber initiation stage (DMT-4) as compared 


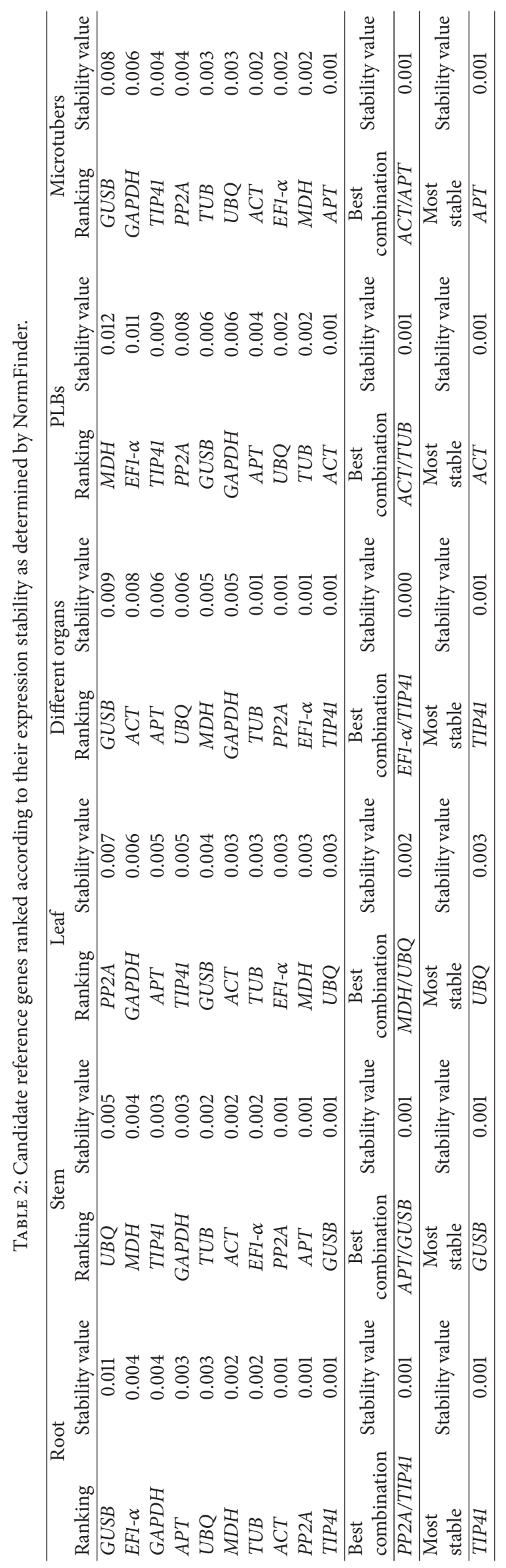




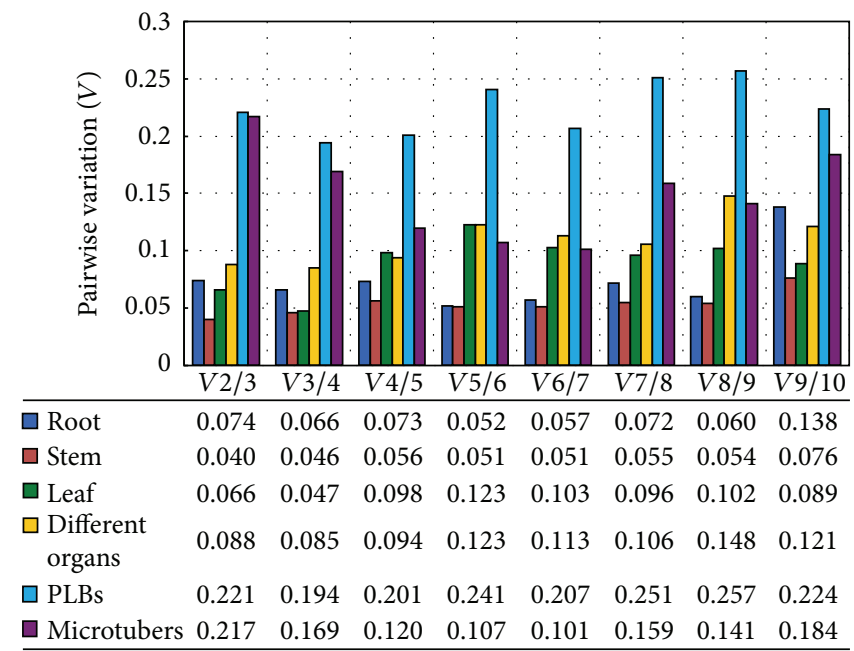

Figure 4: Pairwise variation $(V)$ analysis of the candidate reference genes. The pairwise variation $(V n / n+1)$ was analyzed between two sequential normalization factors NF $n$ and NF $n+1$ that contained an increasing number of reference genes using geNorm software. $V n / n+1<$ 0.15 indicates that the inclusion of an additional reference gene is not required.

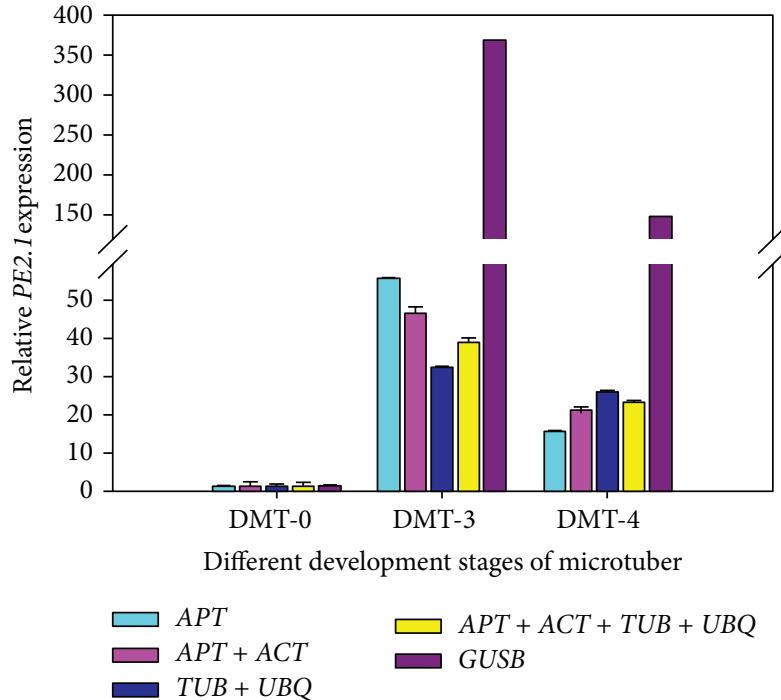

(a)

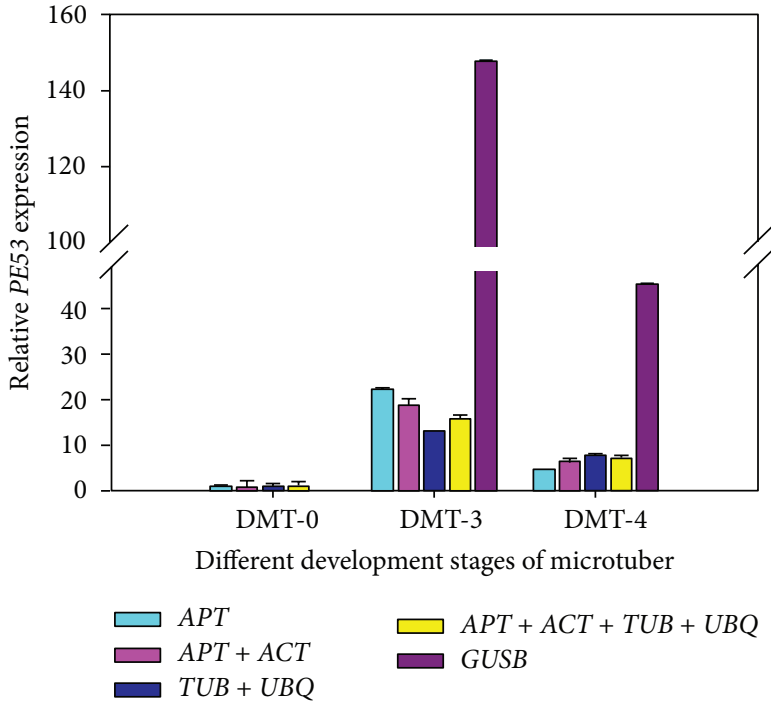

(b)

FIGURE 5: Relative expression levels of PE2.1 (a) and PE53 (b) during three different development stages of microtuber formation, normalized by different combinations of reference genes, as indicated. APT was found to be one of the most stable genes by both geNorm and NormFinder. The combination of TUB and UBQ was the optimal combination as selected by geNorm. The combination of APT and ACT was found to be optimal in the NormFinder analysis. The four most stable reference genes were suggested by both analyses. Standard error bars are indicated.

to its expression at the explants stage (DMT-0). APT was considered to be one of the most stable genes by both the geNorm and the NormFinder programs. When APT was used as the reference gene, the expression levels of PE2.1 were elevated 56- and 15-fold at the DMT-3 and DMT-4 stages, respectively, in comparison with the DMT-0 stage (Figure 5). Thus, the target gene expression profiles of the tested samples varied widely according to the reference gene chosen for normalization.

When the combinations of reference genes were used for normalization, a much more reliable expression profile for
PE2.1 was obtained (Figure 5(a)). TUB and UBQ were found to be the best combination by geNorm, and PE2.1 expression in relation to this combination was consistent with that obtained with the employment of the two best reference genes indicated by NormFinder. Interestingly, the PE2.1 expression profile as normalized by the best gene pairs was equivalent to those obtained when the four best reference genes identified by both programs were used. Similar results were observed for PE53 (Figure 5(b)), suggesting that the use of two genes would be sufficient to get accurate and reliable normalization. These results further emphasized the necessity of evaluating 
reference gene stability before qRT-PCR analysis to avoid quantification errors.

\section{Discussion}

qRT-PCR has become a routine technique for gene expression studies, and normalization of qRT-PCR data with an appropriate internal control gene is essential to obtain results with biological relevance. Internal control genes must be selected with caution. However, it must be noted that there are no universal reference genes that are stably expressed under all biological materials and/or experimental conditions. Accordingly, the stability of reference genes needs to be verified prior to conducting qRT-PCR expression studies in D. opposita. In this study, we analyzed a large group of reference genes; suitable internal controls were identified for use in qRT-PCR analysis of different experimental conditions.

geNorm and NormFinder are two commonly used analysis programs for comparing the expression patterns of candidate reference genes and identifying the best suitable reference gene sets under particular conditions. Differences were observed in geNorm and NormFinder results for the best combinations of reference genes for each of the experimental conditions tested in this study (Table 2, Figure 3). This inconsistency between the two programs was expected, given that they are based on distinct algorithms. geNorm selects two genes with a low intragroup variation and approximately the same nonvanishing intergroup variation. In contrast, NormFinder selects the two best genes with minimal combined inter- and intragroup expression variation [44]. Both methods provide a stability value for each gene and select the best reference gene for normalization. In this study, only a few relevant differences were observed between the two methods. In addition, no matter how the ranking order for the separate results differed, the most unstable gene identified by both geNorm and NormFinder was the same in all sample sets, a finding that has been observed in other studies $[2,13,20$, 41]. Although the best combinations obtained from geNorm and NormFinder can obviously both be used as reference genes in experimental studies, we prefer the NormFinder results because geNorm is known to be influenced by the coregulation of reference genes [43].

In order to determine the suitable reference genes for obtaining accurate and reliable results in gene expression studies, we performed five different normalization approaches for target gene normalization. Significant differences were produced when the least stable gene was used for normalization. When the most reliable reference gene alone was used for normalization, the target gene expression pattern was in accordance with the best combinations of reference genes although there were still slight differences in expression profiles.

Vandesompele et al. [43] outlined, for the first time, a systematic survey of the errors related to the common practice of using only one reference gene. In the following years, increasing evidence has suggested that the application of more than one internal control gene should lead to more reliable results in gene expression studies [2, 62]. Although increasing the number of reference genes for normalization will improve the accuracy of the analysis, this is expensive and time-consuming. Therefore, the number of internal controls should be taken into account if the amount of RNA is limited or if a large number of samples need to be analyzed [41]. It has been suggested that the number of reference genes that need to be used is dependent on the considerations of a researcher's purpose [63]. The expression pattern analysis of PE2.1 and PE53 during microtuber formation emphasized the importance of the choice of the correct reference genes or gene combinations to achieve accurate qRT-PCR results (Figure 5). When single genes were individually used as reference genes, a large fluctuation in the results was observed. More reliable expression profiles of target genes could be obtained when using combinations of reference genes for normalization. According to our results, using two reference genes is a balance between accuracy, cost, and convenience. In addition, our results suggested that different suitable reference genes should be applied according to the different experimental conditions.

To the best of our knowledge, this is the first systematic validation of a set of candidate reference genes in D. opposita for the normalization of gene expression analysis using qRTPCR. Our results provide the foundation for more accurate use of qRT-PCR in the analysis of gene expression in $D$. opposita. Further, our study will also benefit future gene expression studies in other species of the genus Dioscorea.

\section{Conclusion}

Our results suggest that different suitable reference genes or combinations of reference genes for normalization should be applied according to different experimental conditions. EF1- $\alpha$ and TIP41 were identified as the most stable genes for combined studies of leaves, stem, and root, while $M D H$ and $U B Q$ were the best for leaves, $A P T$ and GUSB were the best for stems, and $P P 2 A$ and TIP41 were the best for roots. For PLB formation, $A C T$ and $T U B$ were the best reference genes. For microtuber formation, $A C T$ and $A P T$ were considered to be the best combination.

\author{
Abbreviations \\ ACT: Actin \\ APT: Adenine phosphoribosyltransferase \\ EF1- $\alpha$ : Elongation factor $1-\alpha$ \\ GAPDH: Glyceraldehyde-3-phosphate dehydrogenase \\ GUSB: Beta-glucuronidase \\ $\mathrm{MDH}$ : Malate dehydrogenase \\ MS: $\quad$ Murashige and Skoog (medium) \\ PE: $\quad$ Pectinesterase \\ PP2A: Phosphoprotein phosphatase \\ TIP41: TIP41-like family protein \\ TUB: Beta-tubulin \\ UBQ: Ubiquitin.
}

\section{Competing Interests}

The authors declare that there are no competing interests regarding the publication of this paper. 


\section{Acknowledgments}

This research was funded by the National Nature Science Foundation of China under Grant 81274019; the Program for Innovative Research Teams (in Science and Technology) of the University of Henan Province under Grant 15IRTSTHN020; and the Innovation Scientists and Technicians Troop Construction Projects of Henan Province under Grant C20130037.

\section{References}

[1] S. A. Bustin, V. Benes, J. A. Garson et al., "The MIQE guidelines: minimum information for publication of quantitative real-time PCR experiments," Clinical Chemistry, vol. 55, no. 4, pp. 611-622, 2009.

[2] S. Artico, S. M. Nardeli, O. Brilhante, M. F. Grossi-de-Sa, and M. Alves-Ferreira, "Identification and evaluation of new reference genes in Gossypium hirsutum for accurate normalization of realtime quantitative RT-PCR data," BMC Plant Biology, vol. 10, article 49, 2010.

[3] S. A. Bustin, "Quantification of mRNA using real-time reverse transcription PCR (RT-PCR): trends and problems," Journal of Molecular Endocrinology, vol. 29, no. 1, pp. 23-39, 2002.

[4] M. L. Wong and J. F. Medrano, "Real-time PCR for mRNA quantitation," BioTechniques, vol. 39, no. 1, pp. 75-85, 2005.

[5] S. A. Bustin and S. Dorudi, "Molecular assessment of tumour stage and disease recurrence using PCR- based assays," Molecular Medicine Today, vol. 4, no. 9, pp. 389-396, 1998.

[6] S. A. Bustin, V. G. Gyselman, S. Siddiqi, and S. Dorudi, "Cytokeratin 20 is not a tissue-specific marker for the detection of malignant epithelial cells in the blood of colorectal cancer patients," International Journal of Surgical Investigation, vol. 2, no. 1, pp. 49-57, 2000.

[7] C. Gachon, A. Mingam, and B. Charrier, "Real-time PCR: what relevance to plant studies?" Journal of Experimental Botany, vol. 55, no. 402, pp. 1445-1454, 2004.

[8] N. Nicot, J.-F. Hausman, L. Hoffmann, and D. Evers, "Housekeeping gene selection for real-time RT-PCR normalization in potato during biotic and abiotic stress," Journal of Experimental Botany, vol. 56, no. 421, pp. 2907-2914, 2005.

[9] J. Huggett, K. Dheda, S. Bustin, and A. Zumla, "Real-time RTPCR normalisation; strategies and considerations," Genes and Immunity, vol. 6, no. 4, pp. 279-284, 2005.

[10] K. Goossens, M. Van Poucke, A. Van Soom, J. Vandesompele, A. Van Zeveren, and L. J. Peelman, "Selection of reference genes for quantitative real-time PCR in bovine preimplantation embryos," BMC Developmental Biology, vol. 5, article 27, 2005.

[11] T. Nolan, R. E. Hands, and S. A. Bustin, "Quantification of mRNA using real-time RT-PCR," Nature Protocols, vol. 1, no. 3, pp. 1559-1582, 2006.

[12] T. D. Schmittgen and B. A. Zakrajsek, "Effect of experimental treatment on housekeeping gene expression: validation by real-time, quantitative RT-PCR," Journal of Biochemical and Biophysical Methods, vol. 46, no. 1-2, pp. 69-81, 2000.

[13] H. Wan, Z. Zhao, C. Qian, Y. Sui, A. A. Malik, and J. Chen, "Selection of appropriate reference genes for gene expression studies by quantitative real-time polymerase chain reaction in cucumber," Analytical Biochemistry, vol. 399, no. 2, pp. 257-261, 2010.
[14] L. Chen, H.-Y. Zhong, J.-F. Kuang, J.-G. Li, W.-J. Lu, and J.-Y. Chen, "Validation of reference genes for RT-qPCR studies of gene expression in banana fruit under different experimental conditions," Planta, vol. 234, no. 2, pp. 377-390, 2011.

[15] Z. Wang, Y. Chen, H. Fang et al., "Selection of reference genes for quantitative reverse-transcription polymerase chain reaction normalization in Brassica napus under various stress conditions," Molecular Genetics and Genomics, vol. 289, no. 5, pp. 1023-1035, 2014.

[16] T. Czechowski, M. Stitt, T. Altmann, M. K. Udvardi, and W.-R. Scheible, "Genome-wide identification and testing of superior reference genes for transcript normalization in Arabidopsis," Plant Physiology, vol. 139, no. 1, pp. 5-17, 2005.

[17] T. Remans, K. Smeets, K. Opdenakker, D. Mathijsen, J. Vangronsveld, and A. Cuypers, "Normalisation of real-time RTPCR gene expression measurements in Arabidopsis thaliana exposed to increased metal concentrations," Planta, vol. 227, no. 6, pp. 1343-1349, 2008.

[18] M. Jain, A. Nijhawan, A. K. Tyagi, and J. P. Khurana, "Validation of housekeeping genes as internal control for studying gene expression in rice by quantitative real-time PCR," Biochemical and Biophysical Research Communications, vol. 345, no. 2, pp. 646-651, 2006.

[19] B.-R. Kim, H.-Y. Nam, S.-U. Kim, S.-I. Kim, and Y.-J. Chang, "Normalization of reverse transcription quantitative-PCR with housekeeping genes in rice," Biotechnology Letters, vol. 25, no. 21, pp. 1869-1872, 2003.

[20] M. Expósito-Rodríguez, A. A. Borges, A. Borges-Pérez, and J. A. Pérez, "Selection of internal control genes for quantitative real-time RT-PCR studies during tomato development process," BMC Plant Biology, vol. 8, article 131, 2008.

[21] T. Løvdal and C. Lillo, "Reference gene selection for quantitative real-time PCR normalization in tomato subjected to nitrogen, cold, and light stress," Analytical Biochemistry, vol. 387, no. 2, pp. 238-242, 2009.

[22] G. W. Schmidt and S. K. Delaney, "Stable internal reference genes for normalization of real-time RT-PCR in tobacco (Nicotiana tabacum) during development and abiotic stress," Molecular Genetics and Genomics, vol. 283, no. 3, pp. 233-241, 2010.

[23] B. Jian, B. Liu, Y. Bi, W. Hou, C. Wu, and T. Han, "Validation of internal control for gene expression study in soybean by quantitative real-time PCR," BMC Molecular Biology, vol. 9, article 59, 2008.

[24] M. Libault, S. Thibivilliers, D. D. Bilgin et al., "Identification of four soybean reference genes for gene expression normalization," The Plant Genome, vol. 1, no. 1, pp. 44-54, 2008.

[25] J. V. Die, B. Román, S. Nadal, and C. I. González-Verdejo, "Evaluation of candidate reference genes for expression studies in Pisum sativum under different experimental conditions," Planta, vol. 232, no. 1, pp. 145-153, 2010.

[26] H. M. Iskandar, R. S. Simpson, R. E. Casu, G. D. Bonnett, D. J. Maclean, and J. M. Manners, "Comparison of reference genes for quantitative real-time polymerase chain reaction analysis of gene expression in sugarcane," Plant Molecular Biology Reporter, vol. 22, no. 4, pp. 325-337, 2004.

[27] C. F. Barsalobres-Cavallari, F. E. Severino, M. P. Maluf, and I. G. Maia, "Identification of suitable internal control genes for expression studies in Coffea arabica under different experimental conditions," BMC Molecular Biology, vol. 10, article 1, 2009.

[28] F. Cruz, S. Kalaoun, P. Nobile et al., "Evaluation of coffee reference genes for relative expression studies by quantitative 
real-time RT-PCR," Molecular Breeding, vol. 23, no. 4, pp. 607616, 2009.

[29] S. Jiang, Y. Sun, and S. Wang, "Selection of reference genes in peanut seed by real-time quantitative polymerase chain reaction," International Journal of Food Science and Technology, vol. 46, no. 10, pp. 2191-2196, 2011.

[30] L. Tu, X. Zhang, D. Liu et al., "Suitable internal control genes for qRT-PCR normalization in cotton fiber development and somatic embryogenesis," Chinese Science Bulletin, vol. 52, no. 22, pp. 3110-3117, 2007.

[31] A. R. Paolacci, O. A. Tanzarella, E. Porceddu, and M. Ciaffi, "Identification and validation of reference genes for quantitative RT-PCR normalization in wheat," BMC Molecular Biology, vol. 10, article 11, 2009.

[32] A. Maroufi, E. Van Bockstaele, and M. De Loose, "Validation of reference genes for gene expression analysis in chicory (Cichorium intybus) using quantitative real-time PCR," BMC Molecular Biology, vol. 11, article 15, 2010.

[33] H. Wan, W. Yuan, M. Ruan et al., "Identification of reference genes for reverse transcription quantitative real-time PCR normalization in pepper (Capsicum annuum L.)," Biochemical and Biophysical Research Communications, vol. 416, no. 1-2, pp. 24-30, 2011.

[34] Y. Xu, X. Zhu, Y. Gong, L. Xu, Y. Wang, and L. Liu, "Evaluation of reference genes for gene expression studies in radish (Raphanus sativus L.) using quantitative real-time PCR," Biochemical and Biophysical Research Communications, vol. 424, no. 3, pp. 398403, 2012.

[35] K. E. Reid, N. Olsson, J. Schlosser, F. Peng, and S. T. Lund, “An optimized grapevine RNA isolation procedure and statistical determination of reference genes for real-time RT-PCR during berry development," BMC Plant Biology, vol. 6, article 27, 2006.

[36] Z. Tong, Z. Gao, F. Wang, J. Zhou, and Z. Zhang, "Selection of reliable reference genes for gene expression studies in peach using real-time PCR," BMC Molecular Biology, vol. 10, article 71, 2009.

[37] P. Perini, G. Pasquali, M. Margis-Pinheiro, P. R. D. de Oliviera, and L. F. Revers, "Reference genes for transcriptional analysis of flowering and fruit ripening stages in apple (Malus $\times$ domesticaBorkh.)," Molecular Breeding, vol. 34, pp. 829-842, 2014.

[38] I. Mallona, S. Lischewski, J. Weiss, B. Hause, and M. EgeaCortines, "Validation of reference genes for quantitative realtime PCR during leaf and flower development in Petunia hybrida," BMC Plant Biology, vol. 10, article 4, 2010.

[39] M. Klie and T. Debener, "Identification of superior reference genes for data normalisation of expression studies via quantitative PCR in hybrid roses (Rosa hybrida)," BMC Research Notes, vol. 4, article 518, 2011.

[40] Y. Meng, N. Li, J. Tian, J. Gao, and C. Zhang, "Identification and validation of reference genes for gene expression studies in postharvest rose flower (Rosa hybrida)," Scientia Horticulturae, vol. 158, pp. 16-21, 2013.

[41] Y. L. Lin and Z. X. Lai, "Reference gene selection for qPCR analysis during somatic embryogenesis in longan tree," Plant Science, vol. 178, no. 4, pp. 359-365, 2010.

[42] A. M. Brunner, I. A. Yakovlev, and S. H. Strauss, "Validating internal controls for quantitative plant gene expression studies," BMC Plant Biology, vol. 4, article 14, 2004.

[43] J. Vandesompele, K. De Preter, F. Pattyn et al., "Accurate normalization of real-time quantitative RT-PCR data by geometric averaging of multiple internal control genes," Genome Biology, vol. 3, no. 7, Article ID research0034.1, pp. 1-12, 2002.
[44] C. L. Andersen, J. L. Jensen, and T. F. Ørntoft, "Normalization of real-time quantitative reverse transcription-PCR data: a modelbased variance estimation approach to identify genes suited for normalization, applied to bladder and colon cancer data sets," Cancer Research, vol. 64, no. 15, pp. 5245-5250, 2004.

[45] M. W. Pfaffl, A. Tichopad, C. Prgomet, and T. P. Neuvians, "Determination of stable housekeeping genes, differentially regulated target genes and sample integrity: BestKeeper-excelbased tool using pair-wise correlations," Biotechnology Letters, vol. 26, no. 6, pp. 509-515, 2004.

[46] J. Hellemans, G. Mortier, A. De Paepe, F. Speleman, and J. Vandesompele, "qBase relative quantification framework and software for management and automated analysis of real-time quantitative PCR data," Genome Biology, vol. 8, no. 2, p. R19, 2007.

[47] Y. S. Chan and T. B. Ng, "A lectin with highly potent inhibitory activity toward breast cancer cells from edible tubers of Dioscorea opposita cv. nagaimo," PLoS ONE, vol. 8, no. 1, Article ID e54212, 2013.

[48] T. Nagai and T. Nagashima, "Functional properties of dioscorin, a soluble viscous protein from Japanese yam (Dioscorea opposita thunb.) tuber mucilage tororo," Zeitschrift fur NaturforschungSection C Journal of Biosciences, vol. 61, no. 11-12, pp. 792-798, 2006.

[49] N. Nishimura, H. Tanabe, T. Yamamoto, and M. Fukushima, "Raw Chinese Yam (Dioscorea opposita) promotes cecalfermentation and reduces plasma Non-HDL cholesterol concentration in rats," Journal of Nutritional Science and Vitaminology (Tokyo), vol. 57, no. 5, pp. 340-347, 2011.

[50] M. H. Yang, Y.-W. Chin, K. D. Yoon, and J. Kim, "Phenolic compounds with pancreatic lipase inhibitory activity from Korean yam (Dioscorea opposita)," Journal of Enzyme Inhibition and Medicinal Chemistry, vol. 29, no. 1, pp. 1-6, 2014.

[51] M. H. Yang, K. D. Yoon, Y.-W. Chin et al., "Neuroprotective effects of Dioscorea opposita on scopolamine-induced memory impairment in in vivo behavioral tests and in vitro assays," Journal of Ethnopharmacology, vol. 121, no. 1, pp. 130-134, 2009.

[52] A. L. Julkifle, R. Poobathy, R. Samian, and S. Subramaniam, "Histological analyses of PLBs of Dendrobium sonia-28 in the recognition of cell competence for regeneration and Agrobacterium infection," Plant OMICS, vol. 5, no. 6, pp. 514-517, 2012.

[53] X. Peng, P. Zhou, L. Zhang, J. Peng, and S. Zhou, "In vitro propagation of PLB (protocrom-like body) of Dioscorea zingiberensis C. H. Wright," Journal of Plant Genetic Resources, vol. 11, pp. 629-634, 2010.

[54] M. Li, J. Li, W. Liu et al., "A protocol for in vitro production of microtubers in Chinese yam (Dioscorea opposita)," Bioscience, Biotechnology and Biochemistry, vol. 78, no. 6, pp. 1005-1009, 2014.

[55] T. Murashige and F. Skoog, "A revised medium for rapid growth and bio assays with tobacco tissue cultures," Physiologia Plantarum, vol. 15, no. 3, pp. 473-497, 1962.

[56] M. Li, J. Li, Y. Wang et al., "A simple method for microtuber production in Dioscorea opposita using single nodal segments," Pakistan Journal of Botany, vol. 47, no. 2, pp. 665-668, 2015.

[57] M. W. Pfaffl, "A new mathematical model for relative quantification in real-time RT-PCR," Nucleic Acids Research, vol. 29, no. 9, article e45, 2001.

[58] A. Radonić, S. Thulke, I. M. Mackay, O. Landt, W. Siegert, and A. Nitsche, "Guideline to reference gene selection for quantitative real-time PCR," Biochemical and Biophysical Research Communications, vol. 313, no. 4, pp. 856-862, 2004. 
[59] C. Infante, M. P. Matsuoka, E. Asensio, J. P. Cañavate, M. Reith, and M. Manchado, "Selection of housekeeping genes for gene expression studies in larvae from flatfish using real-time PCR," BMC Molecular Biology, vol. 9, article 28, 2008.

[60] N. J. Walker, "A technique whose time has come," Science, vol. 296, no. 5567, pp. 557-559, 2002.

[61] K. J. Livak and T. D. Schmittgen, "Analysis of relative gene expression data using real-time quantitative PCR and the $2^{-\Delta \Delta C_{T}}$ method," Methods, vol. 25, no. 4, pp. 402-408, 2001.

[62] C. Gu, S. Chen, Z. Liu et al., "Reference gene selection for quantitative real-time PCR in chrysanthemum subjected to biotic and abiotic stress," Molecular Biotechnology, vol. 49, no. 2, pp. 192-197, 2011.

[63] R. Hu, C. Fan, H. Li, Q. Zhang, and Y.-F. Fu, "Evaluation of putative reference genes for gene expression normalization in soybean by quantitative real-time RT-PCR," BMC Molecular Bio$\log y$, vol. 10, article 93, 2009. 

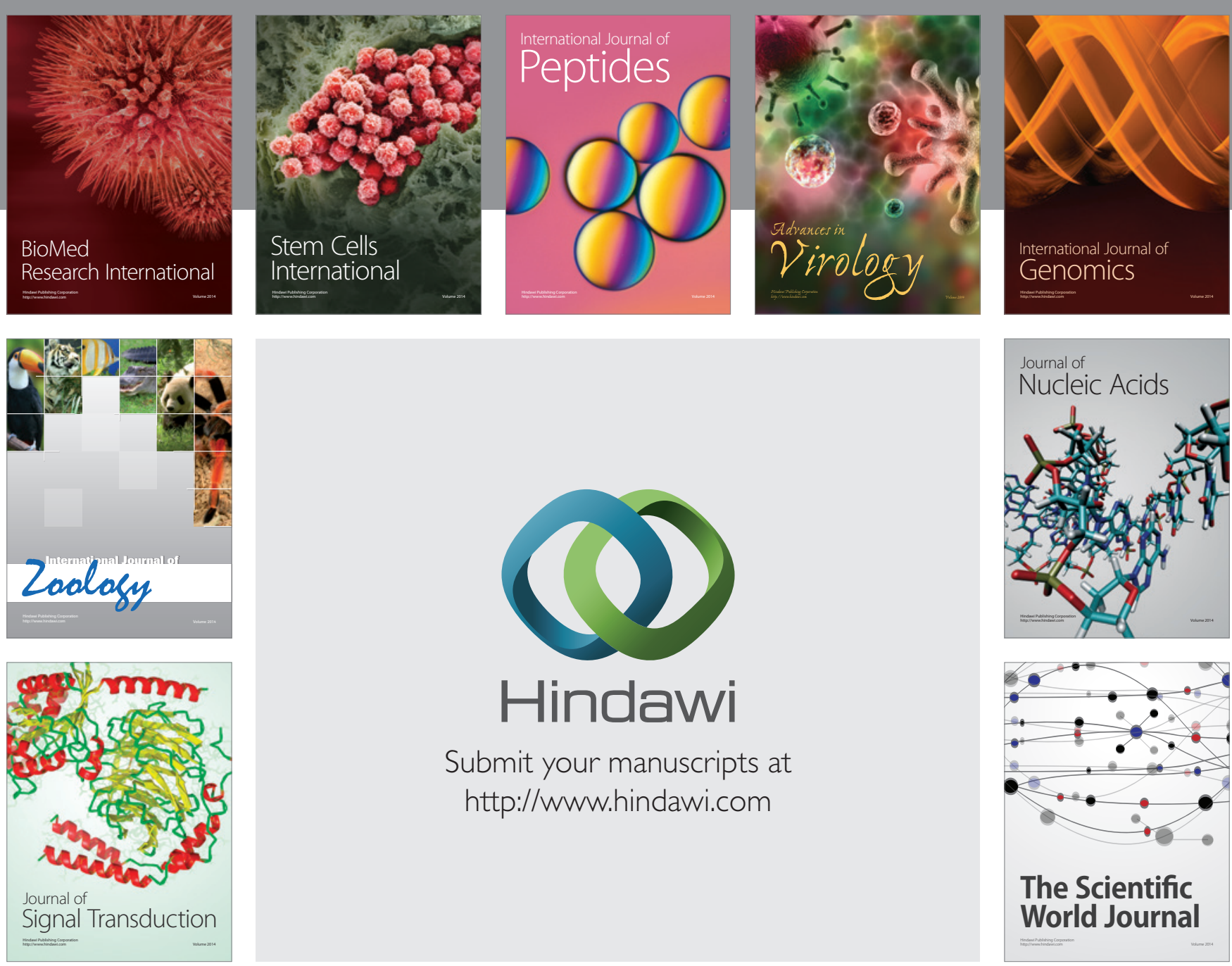

Submit your manuscripts at

http://www.hindawi.com
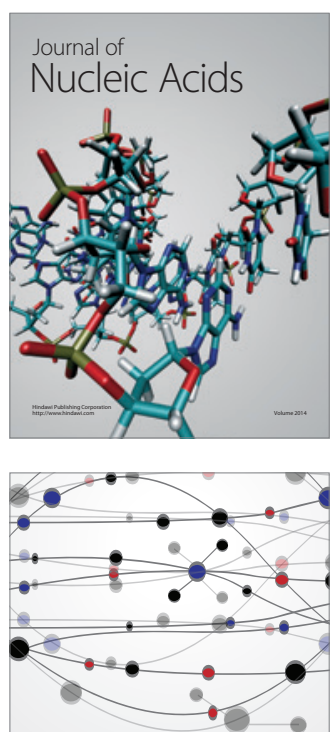

The Scientific World Journal
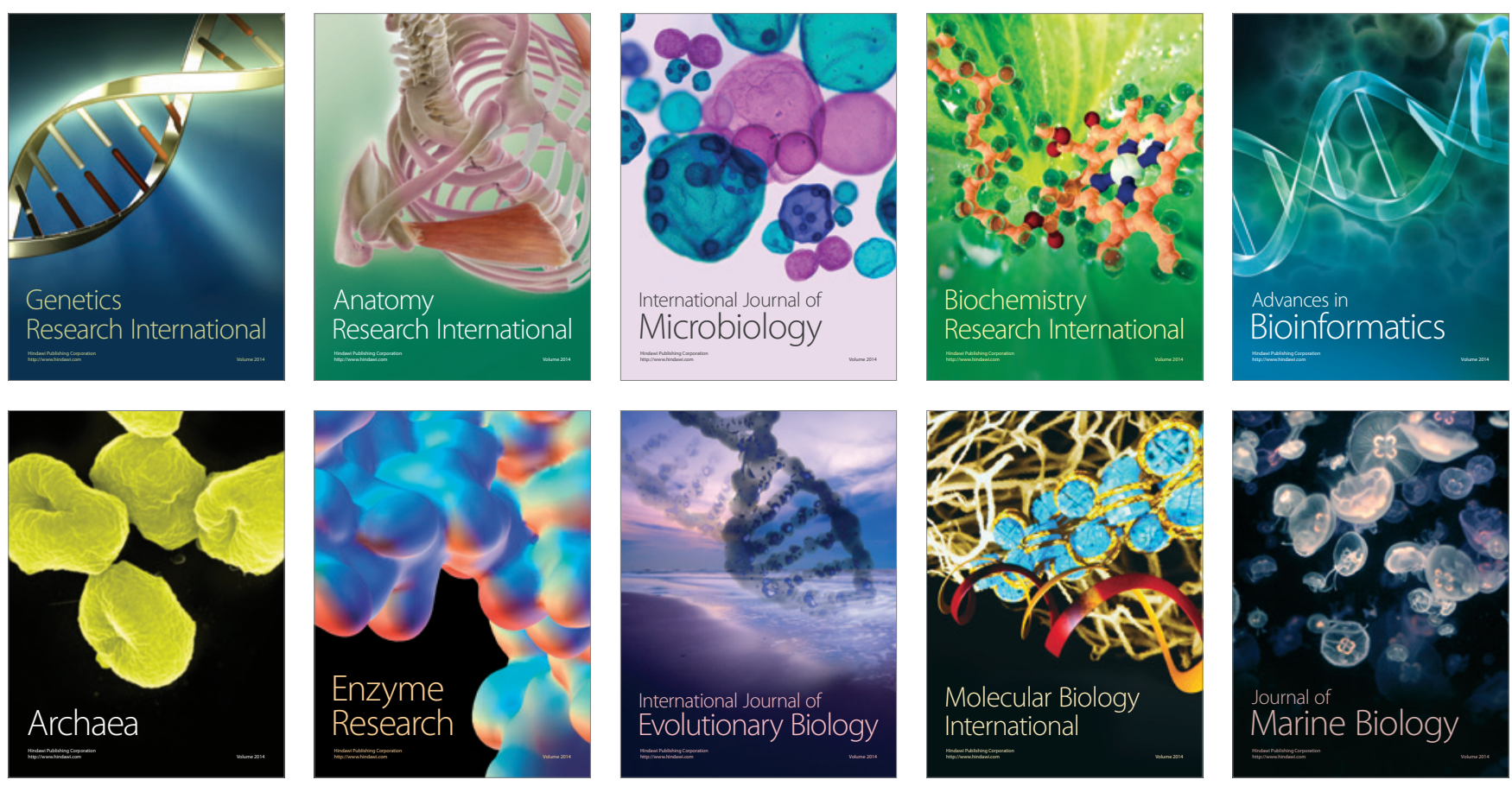